\title{
Effects of Large-Scale Land Acquisition on Livelihood Assets in the Pru East District of Ghana
}

\author{
Charles Quansah ${ }^{1} \quad$ William Owusu Ansah ${ }^{2} \quad$ Ronald Osei Mensah ${ }^{3}$ \\ 1.Ph.D. Graduate, Department of Geography and Rural Development, Kwame Nkrumah University of Science \\ and Technology (KNUST) \\ 2.MSc. Student, Department of Planning, Kwame Nkrumah University of Science and Technology (KNUST) \\ 3.Ph.D. Student, Department of Sociology and Anthropology, University of Cape Coast (UCC)
}

\begin{abstract}
The activities of multi-national companies have affected the livelihood of smallholder farmer in the Pru East, though a lot of research work has been done on large scale land acquisition but this study focus on how it affects livelihood asset of smallholder farmers in the Pru East District. Over the past ten years, the Government of Ghana have leased out large tracts of land for investors, mainly foreign investors. Survey research approach was used for the study. A multi-stage sampling technique was employed and a sample size of 332 households was used for the study. The study used five indicators of the Livelihood Effect Index (LEI) espoused by Downing et al., (2001) to determine the effects of large-scale land acquisition on the livelihood of smallholder farming households. Large scale land acquisition has a significant positive moderate effect on the employment, healthcare and food security but, has a significant negative high effect on income levels of smallholder farming households. However, large scale land acquisition has no significant effect on the nutritional status of farming households in the Pru East district of the Bono East region. Kobre and Kadue communities with an LEI of 0.53 suggests that livelihoods of farming households in these two communities are the most effected with large scale land acquisition. The study also recommends that MMDAs must formulate by-laws to ensure that large scale land investors employ people from the host communities of the projects.
\end{abstract}

Keywords: livelihood asset, large scale land acquisition, smallholder farmer, human capital asset, natural capital asset, financial capital asset, social capital asset.

DOI: $10.7176 / \mathrm{JEES} / 10-2-08$

Publication date: February $29^{\text {th }} 2020$

\subsection{Introduction}

In recent times, Ghana has become one of the destinations for large scale land deals in Africa, attracting high foreign investment in the agricultural sector. Over the past ten years, the Government of Ghana have leased out large tracts of land for investors, mainly foreign investors. One main feature of such large-scale land deals in Ghana has been that lands given to foreign investors are larger than those given to domestic investors. The reason has often being that the government perceives foreign firms to possess more capital and technologies than the domestic firms to carry out big investments successfully (Giddens, 1979 cited in Scoones, 1998). In addition, the government offers very generous incentives for foreign investors including lower capital requirement, guarantee against expropriation or nationalization and attractive financial incentives, such as exemptions of income tax on exports (tax holidays) and free custom duties on imports (Rahmato 2011; Tamrat 2010).

Schoneveld (2011) observe that Sub-Saharan Africa (SSA) has become an attractive destination for these investors. Woodhouse (2012) attributes the SSA's attractiveness to large scale land investments to its weak legislative and regulatory frameworks to protect the interests of existing land users or the general public. Makutsa (2010) adds that the conventional perception that Africa has vast and suitable lands for agricultural purposes has made the region attractive to large scale land investors. The Food and Agriculture Organisation [FAO], (2008) and Right and Resource Initiative (2012) observe that the phenomenon displaces families from their homes and farmers from their fields. This has the potential to interfere with their livelihoods and ultimately deprive them of their basic needs (Thurmond, 2007).

One plausible explanation for allowing these investments in the Bono East region is their perceived positive effects on employment, household and national incomes, and the country's competitiveness in regional and international trade (Knight, 2010; Schoneveld, German and Nutakor, 2010; Bosch and Zeller, 2013). These investments therefore have the potential to improve the living conditions of smallholder farmers who lose their lands. They make significant impacts on rural economies through infrastructure development.

Clearly, literature is silent on clarifying the effects of large-scale biodiesel (e.g. jathropha) investments on the livelihoods of affected smallholder farmers. While some researchers see the effects as positive (Knight, 2010; Schoneveld et al., 2010; Bosch and Zeller, 2013); others consider them as negative (World Bank, 2002: 157; Schoneveld et al., 2010; Hughes et al., 2011; Sindayigaya, 2011). The negative effects are the bases for the ongoing discourse on land right issues, responsible agricultural investments and food security (Liversage, 2010). 
The activities of land deals of the Solar Harvest Limited, Agroris company from Italy, Smart Oil Ghana limited, Fawoman company and Kirminic Estate Limited in various areas in the Bono East region have displaced several smallholder farmers whose livelihoods depended on the land (Tsikata and Yaro, 2011). The activities of these companies have affected the livelihood of smallholder farmer in the Pru East, though a lot of research work has been done on large scale land acquisition but this study focus on how it affects livelihood asset of smallholder farmers in the Pru East District.

\subsection{Literature Review}

\subsection{Smallholder farmers}

Smallholder farmers are defined in various ways depending on the context, country and even ecological zone. Often the term 'smallholder' is interchangeably used with 'small-scale', 'resource poor' and sometimes 'peasant farmer (Berdegué, 2013) whilst authors like Cousins (2010) thought that 'smallholder' and 'small-scale' cannot be used interchangeably as he went further to elucidate on the dimensions of the term 'small-scale'

Throughout literature, there exist strong relationship between smallholdership, agriculture and rural poverty. Kydd (2002) for instance indicate that the majority of the world's extremely poor people live in rural areas and have livelihoods which are bound closely to smallholder agriculture as farmers, labourers, transporters, marketers and processors of produce and as suppliers of non-agricultural services to households whose income is principally agriculture-derived (Kydd, 2002). Smallholders are often characterized as forming part of the 'rural poor', together with subsistence producers and landless households. The emphasis is often on commonalities rather than differences e.g. in assets, income, investment and class identity (Cousins, 2010). The definition of smallholders could be characteristically based on agricultural activities or on size of land operated. Thus, the definition could be done subjectively (qualitative criteria) or objectively (quantitative criteria). According to Calcaterra (2013), farm size (quantitative criteria) is a frequently used indicator, however, the relevance of one fixed number may differ across sectors and countries (e.g. a 25-ha sugarcane farmer in Rwanda may be considered as a large-scale farmer, while a 200 ha soybean farmer in Brazil as a small-scale farmers).

\subsection{Livelihood}

The term 'livelihood' is complex to define. An attempt to develop a universally accepted definition has been said to be difficult (Department for International Development [DFID], 2000). Some definitions have however been developed through extensive learning and practice to reflect the complexity of the concept. The most widely used definition of a livelihood system is from the work of Chambers and Conway (1992). They defined the concept to comprise people, their capabilities and their means of living, including food, income and assets. The authors indicate that livelihood has a tripartite relationship where people survive by using their capabilities to make productive uses of their assets, which are both tangible (resources and stores) and intangible (claims and access).

According to Lakwo (2006) and Murray (2001), a livelihood comprises the capabilities, assets (i.e. stores, resources, claims and access) and activities required for a means of living. These assets are generally recognised within sustainable livelihoods theory as also identified by Carney (1998) and Ellis (2000) are summarised below:

i. Natural (environmental) capital: natural resources (land, water, wildlife, biodiversity, environmental resources, and others).

ii. Physical capital: basic infrastructure (water, sanitation, energy, transport and communications), housing and the means and equipment of production.

iii. Human capital: health, knowledge, skills, information, ability to labour.

iv. Social capital: social resources (relationships of trust, membership of groups, networks, access to wider institutions).

v. Financial capital: financial resources available (regular remittances or pensions, savings, supplies of credit).

\subsection{Effects of Large-Scale Land Acquisition on Livelihood}

Despite evidenced researches on the ability of large scale land acquisition to providing a safe, cost effective and sustainable bioenergy which gained grounds after the escalating global oil prices in 2006, (Schoneveld and German, n.d), a lot of questions have been raised by many researchers and some developing countries concerning the net impacts of large scale land acquisition for jatropha plantation on the livelihoods of people in project communities. Schoneveld et al., (2011) summarizes that, Large Scale land acquisition for jatropha and other plantation could either make invaluable contribution to reducing rural poverty or worsened the socio-economic conditions and environment of project-based communities.

Supportively, Danso (2015) opines that, jatropha and other plantation production could be used as a means to developing rural communities when the project adheres and considers the traditional land tenure systems and also engages the people of the host communities. Levidow and Helena (2010), also sees the positive aspect of large- 
scale land acquisition purposively for jatropha, positing that large-scale land acquisition for plantation and biofuel production will not divert resources from food production.

Danso (2015) had noted that the activities of Bio-fuel Africa Ltd had led to the generation of additional social assets in project host communities including grind-mill, dams, and a clinic. Improving on the human capital, Vermeulen et al., (2010) relates a case in Mali where the company had provided technical assistance to farmers in order to enable them improve on their agricultural activities.

Some instances of large-scale land acquisition have impacted on the financial assets of host communities. Wujenja and Wonani (2012) upon studying Export Trading Company (ETC), found that the project had contributed to long term public revenues. Also, Abbink (2011) presents a case of foreign entrepreneurs in Ethiopia who have contributed to the revenue base of the government by paying land lease fees. A local farmers union in Mali has been able to invest and holds a $20 \%$ share in a Dutch funded project, (Vermeulen et al., 2010).

In contrast to the views, a number of researches stand tall disapproving large scale land acquisition for plantation; postulating that the situation has rather worsened livelihoods of host communities. Matondi et al., (n.d) adds that there still persist arguments on the local benefits among advocates of biofuels in terms of employment creation, infrastructure, higher standards of living, etc. In some extreme instances, Levidow and Helena (2010) notes that large-scale jatropha cultivation has actually generated conflicts over resources in Africa (notably in Mozambique and Tanzania) and Asia. The disapproval comes in the context where most projects has led to the lost or damage to the livelihood assets of host communities with Schoneveld (2010) warning that the phenomenon can significantly exacerbate rural poverty as communities lose access to vital livelihood resources.

Buttressing the stance of the opponents to large scale land acquisition for plantations, (Schoneveld, 2010; Action-Aid, 2010a, 23), cited in Daley, (2011) recounts the ordeal women farmers in Mozambique and Tanzania wallowed in after losing their farm lands to plantations investors. The farmers have reportedly lost their assets, the only farm lands on which their livelihood depended. The situation has reportedly resulted in hunger and reduction in the level of productivity of these farmers as they resorted to unfavorable alternative means of survival. ActionAid (2010b:28) presented a similar case, cited in Daley, (2011) that a good number of Ghanaians and Senegalese have lost their "marginal" lands on which was their main source of food, fuel and incomes.

Finco and Doppler, (2010) presented that the food insecurity situation among smallholders was worsened after their farms (on which they cultivated maize, rice and cassava) were replaced with plantation cultivations. Exacerbating the loss of assets by most people, Levidow and Helena (2010) presents a case in Mozambique where the plantation led to the attraction of pests which destroyed nearby food crops. This asset can be stored, accumulated, exchanged, or depleted and put to work to generate a flow of income or other benefits (Rakodi 2002).

\subsection{Materials and Methods}

\subsection{Description of the Study Site}

The Pru East District was created on the 18th of February, 2004 under Legislative Instrument (L.I) 1778 of 2004. Pru District was created out of the then Atebubu District. The physical, economic and socio-cultural conditions have shaped and influenced lives in the Pru District. It is therefore relevant to put these issues into perspective to enable a fair appreciation of the current state of the district. There are core natural and anthropogenic factors that have influenced economic production, consumption, reproduction, health, sanitation and the overall welfare of the people in the Pru East district. The study communities include Kobre, Kadue, Abease, Prang and Adjentura.

The Pru district lies between Longitudes 0030" W and 1026 " W and Latitudes 70 50" N and 80 22" N. It shares boundaries with seven other districts, namely East Gonja to the North (Northern Region), Sene East and West to the East, Nkoranza and Atebubu-Amantin to the South and Kintampo-North and South to the West, all in the Bono East Region. The District covers an area of $3220.7 \mathrm{kmsq}$ 
Figure 1: Pru District Map Indicating The Study Communities

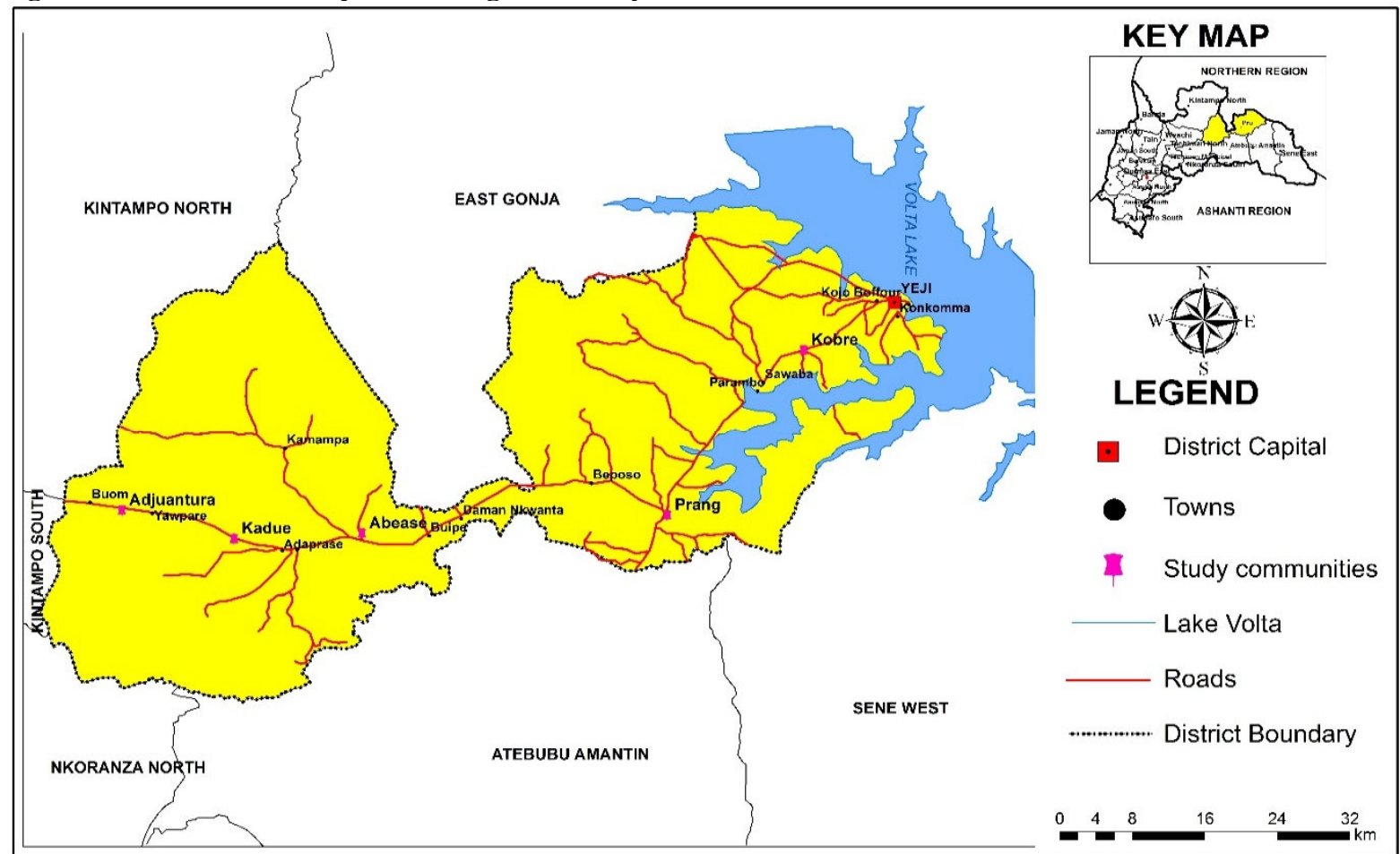

Source: Ghana Statistical Survey (2015)

\subsection{Research Approach}

Survey research approach was used for the study. The survey research was considered to be most appropriate research approach to provide the required quantitative and qualitative descriptions of the effect of large-scale land acquisition on the livelihood of smallholder famers in the Pru East District. Data from farming households were gathered using structured questionnaires.

The research further collected a mixture of quantitative and qualitative (descriptive) data. The approach makes provision for quantitative method (designed to collect numbers) and qualitative method (designed to collect words/descriptive in nature). The study therefore used a combination of quantitative and qualitative methods to answer the research questions. The methodological eclecticism inherent in the mixed research design results in superior results (Johnson \& Onwuegbuzie, 2009). The strength of this strategy is that the weakness of one will be compensated for by using an alternative method (Bryman, 2008 cited in Alatinga and Fielmua, 2011). Focus group discussions have also been used to obtain qualitative data from farmer-based associations in the Pru East District. The quantitative data were obtained through a cross-sectional survey from smallholder farming households in the study communities in the Pru District.

\subsubsection{Sample Size for the study}

Based on the sample frame of 2,554 households in the communities, a sample size of 332 households was used for the study. The sample size was determined from the sampling frames using Slovin's mathematical method expressed by equation (1)

$n=\frac{N}{1+N(\ell)^{2}}$

Where ' $\mathrm{n}$ ' is the sample size, " $\mathrm{N}$ " is the sample frame and " $\ell$ " ' is the error margin. The use of the formula should contribute to ensuring reliability and validity in the research.

The sampling frame is the total number of units likely to be included in the study. In determining the sample size for the cross-sectional survey, a total of 332 sampled small holder farming households were obtained from the communities in the Pru East District at 95\% confidence level and 5\% error margin.

\subsection{Sampling Techniques}

\subsubsection{The Cross-sectional Survey}

A multi-stage sampling technique was employed. The Pru East district in the Bono East region was purposively selected based on the reason that it is the most effected with activities of large-scale land acquisition in Ghana. The second stage involved cluster sampling to ensure that all communities affected by large scale land acquisition 
are represented in the final sample. The last stage involved proportionate simple random sampling technique which was applied to select the smallholder farming households in each cluster (study communities).

\subsection{Results and Discussions}

\subsection{Socio-Demographic Characteristics of Respondents}

The socio-demographic characteristics of farming households determine the magnitude of the effect of large-scale land acquisition on their livelihoods and the strategy of coping and adapting to these effects. The sociodemographic characteristics of farming households considered by this research are age of household head, household size, household income per annum, total acres of farm land owned by households, number of acres of farm land lost by farming households to large scale land investors, sex of household head and the educational level of household head.

Table 1: Descriptive Statistics of Sampled Smallholder Farmers

\begin{tabular}{lllll}
\hline Variable & Mean & Standard Deviation & Min & Max \\
\hline Age of HHH & 35.49 & 1.27 & 24 & 58 \\
Household Size & 5.40 & 3.00 & 1 & 18 \\
Household income & 1700.83 & 78.04 & 180.00 & 3900.00 \\
Land size owned By HH (acres) & 8,87 & 3.92 & 4 & 23 \\
Land lost by HH to investors & 4.53 & 3.66 & 0 & 13
\end{tabular}

The youngest household head was 24 years while the eldest household head was 58 years as shown in Table 1. The average age of household heads in the Pru East district was 35.49 years with a standard deviation of 1.27. This shows that the sampled households comprise of youthful members who can energetically carry out farming activities. Meanwhile, the minimum and maximum household sizes were 1 and 18 respectively with an average of 5.40 members. Larger household size is a source of labour for farming activities by a household. The mean household income was GHф1700.83 with a standard deviation of 78.04. The minimum and maximum household incomes were $\mathrm{GH} \notin 180.00$ and $\mathrm{GH} \notin 3900.00$ respectively.

The size of farm land owned by a household also determines the extent to which households' livelihoods are adversely affected by large scale land acquisition since there will still be enough farm land for cultivation by the household after relinquishing part of their lands to large scale land investors. The minimum and maximum farm land owned by sampled households was 4 acres and 23 acres respectively while the average farm land owned by households was 8.87 acres with a standard deviation of 3.92 acres. This reflects a typical smallholder farmers' in Ghana. Similarly, number of acres of land lost by farming households to large scale land investors influences the magnitude of effect on households' livelihoods. The minimum and maximum size of land lost by households to large scale land investors were 0 and 13 respectively. Averagely, each household lost 4.53 acres of land through large scale land acquisition.

About 73 percent of sampled households in the combined data were headed by males while 27 percent were headed by females. Kobre community had the highest number of households headed by males (94) and households headed by females (29) while Adjentura community recorded the least number of households headed by males (18) and households headed by females (9). In the literature, large scale land acquisition has a disproportionate high effect on the livelihood of households headed by females than households headed by males.

\subsection{Effects of Large-scale Land Acquisition on the Livelihood Assets of Smallholder Farmers}

This research used five indicators of the Livelihood Effect Index (LEI) espoused by Downing et al., (2001) to determine the effects of large-scale land acquisition on the livelihood of smallholder farming households. The indicators of the LEI are human, natural, social, financial and physical capitals. Each of the indicators consists of several sub-indicators.

Based on the FANRPAN (2011) classification of Human Vulnerability Index (HVI), the computed LEI was used to categorise households into three categories: lowly effected, moderately effected and highly effected households. Households with LEI range of 0 to 0.47 experience low effect of large-scale land acquisition on their livelihood. Households with computed LEI of 0.471 to 0.64 have their livelihood being moderately reverted by the large-scale land acquisition while households with LEI of 0.641 to 1.00 suggests high effect of large scale land acquisition on their livelihoods. This is presented in Table 2. This categorisation forms the basis for discussion status or magnitude of effect of large-scale land acquisition on farming households' livelihoods.

Table 2: Categorised Households' Status to the Effect of Large-Scale Land Acquisition

\begin{tabular}{ll}
\hline Status of Effect & Range of LEI \\
\hline Lowly Effected & $0-0.47$ \\
Moderately Effected & $0.471-0.64$ \\
Highly Effected & $0.641-1.00$ \\
\hline
\end{tabular}




\subsection{Effect of Large-Scale Land Acquisition on Human Capital Assets}

This indicator bothers on the effect of large-scale land acquisition on the demographic structure, health and food security which affects the overall human capacity of the household. The human indicator consists of nine subindicators which were computed for each community and the Pru East district. Kobre community with subindicator index of 0.88 suggests that households in the community suffer the highest effect of large scale land acquisition on their nutrition than the other four communities, while the index of 0.83 for the Pru East district implies that averagely, the effect of large scale land acquisition on the nutritional level of farming households is high. All farming households in the Kadue community reported loss of life, injury or new disease outbreak associated with large scale land acquisition. In terms of the district, the index of 0.60 suggests that the effect of large-scale land acquisition on loss of lives, injuries and/or new disease outbreak among farming households is moderate. Age is another factor that determines the extent to which a household suffers the effect of large-scale land acquisition.

On the one hand, older households are more experienced to smoothly adjust to the effect of large-scale land acquisition than younger households. Contrary, younger households can engage in other sources of livelihood and are also energetic to regularly visit new farm land which may be far from home. The effect of large-scale land acquisition on farming households in the district depending on the age of household head is low (0.39). The activities of some companies that acquire large scales of land tend to be injuries and harmful to the health of the inhabitants of the operating community. It may result in new epidemics due to land, water and air pollution emanating from the activities of the company. The computed indices revealed high effect of large-scale land acquisition on the livelihood of farming households in all the communities and for the district (0.83).

The effect of large-scale land acquisition on food security of farming households was low for all the five communities and for the combined Pru East district index (0.38). In terms of crops diversification, the Prang community with an index of 0.60 is the most affected community. The combined Pru East district index of 0.49 suggests a moderate effect of large-scale land acquisition on the livelihood of farming households. Farming households with high crop diversification experiences less effect of large-scale land acquisition on their livelihood than households with low crop diversification. All farming households in Adjentura and Kadue communities attributed the reduction in crop output to large scale land investments. On vocational training, most farming households reported to have members acquired skills to undertake other source of livelihood and thus, lowly effected by the large-scale land acquisition. Large scale land acquisition has a high effect $(0.83)$ on the education of farming households in the Pru East district with the Kobre community being the hardest hit (0.88). It was revealed in the community focus group discussions that children of school going age are engaged by the largescale land activity companies leading to their drop out of school. Also, some households reported that the main source of income to finance the education of pupils in the study communities has been farming. Taking over of households' farm lands by large scale land investors undoubtedly hinders the ability of such households to continue to finance the education of their members due to reduced incomes resulting from reduced output attributable to large farm lands acquired by investors.

\subsection{Effect of Large-Scale Land Acquisition on Natural Capital Assets}

The natural capital indicator include in its' domain the water, land, forest and other natural resources which contribute to the livelihood of farming households. The natural capital indicator consists of twelve sub-indicators. Minority of the sampled farming households reported losing more acres of their farm lands to large scale land investors and thus, large scale land acquisition exerts low effect on the size of farm lands of farming households in the Pru East district as showed by the computed index (0.35). Kobre community is reported to have lost the highest size of farm lands by farming households losing farm lands to large scale land investors in Pru East district. Prang community has the highest farming households who were not part of the land acquisition process in the district. The computed index of 0.22 for the Pru East district implies a low effect of large-scale land acquisition on the livelihood of farming households in the district based on households not participating in the land acquisition process.

Majority of farming households in all the study communities attributed changes in the distance to their farms to large scale land acquisition and the computed index for the Pru East district (0.80) indicates that large scale land acquisition posts a high effect on the distance to farm sites of farming households. The results also revealed that most farming households in all the study communities lost farm lands to large scale land investors. The computed index of 0.79 indicates that large scale land acquisition has a high effect on the percentage of farming households losing their farm lands in the Pru East district. Farming households who lost more acres of their farm lands to large scale land investors and have relocated to new far farm lands have to reduce their cultivated farm sizes and even the number of days they visit the farms. The large-scale land acquisition negatively impacts on their livelihoods especially when they were not compensated by for losing their farm lands. Apart from farming households in the Kobre community who reported moderate land related conflicts among households (0.52); households in all other communities including the combined Pru East district index (0.41) revealed a low effect of large-scale land 
acquisition on land related conflicts among farming households. Conflict is a social disintegrative factor and hinders peaceful co-existences and cohesion of households.

All farming households in Kobre community depend on only forest-based energy such as charcoal and fire wood for cooking. This suggests that households in the Kobre community are the worst affected with large scale land acquisition. The computed index for the Pru East district (0.98) implies a high effect of large-scale land acquisition on farming households' source of forest-based products for cooking. When lands are acquired by investors, households are banned from felling trees on such land for firewood and charcoal burning which they use for domestic cooking. Again, all farming households in the Kobre and Adjentura communities reported depletion in their forest products due to large scale land acquisition by investors. The computed combined index of 0.77 for the Pru East district suggest that large scale land acquisition has a high effect on the depletion of forest products in the district. Yet, the computed index for the Pru East district (0.93) shows a high effect of large-scale land acquisition on farming households collecting water from natural sources such as streams, rain, rivers and ponds.

Kobre community had all farming households collecting water from natural sources and hence, is the most affected with the effect of large-scale land acquisition on natural water sources. Turning to households without consistent water supply, the Abease community reported the highest percentage of farming households without regular water supply. The computed index of 0.75 for the Pru East district suggests that large scale land acquisition posts high effect to consistent water supply to farming households in the district. The findings also revealed that almost all farming households in the Kobre community reported depletion in natural water sources. The index of 0.90 computed for the Pru East district suggests high effect of large-scale land acquisition on natural water sources in the district. Land, forest and water are the main natural resources available to farming households in the Pru East district. Losing ownership of these natural resources to other investors is synonymous with losing entitlement to, control of and benefit derived from these resources, thereby rendering farming households' livelihood more precarious. Mutopo et al., (2015) found that in Mwenezi, Zimbabwe Bio Energy company used a fence to ensures its' exclusive access to water because the company assumed legal exclusive ownership of the natural resources on the land including water bodies. Neighbouring communities were therefore restricted from accessing water resources within this vicinity.

\subsection{Effect of Large-Scale Land Acquisition on Social Capital Assets}

The social capital which refers to the demographic characteristics and network or relations of farming households. The research focuses on the five sub-indicators constitute the social capital indicator. Though Kadue community has the highest average household size, the computed indices suggest that large scale land acquisition has a low effect on the average household size of all the study communities and the combined Pru East district (0.26). Kobre community has the highest percentage of households where household head has not attended school. The computed district index of 0.53 implies that large scale land acquisition has a moderate effect on the livelihood of farming household as a results of household heads not attending school. Uneducated household heads lack understanding of certain issues that affect the livelihood of their households. In a typical Ghanaian society, female are marginalised in vital decision making and also resource distribution which adversely impacts on their livelihoods. Abease reported the highest percentage of households headed by females. But, the computed index for the district (0.27) suggests that large scale land acquisition has a low effect on households headed by females in the district. Some farming households' resort to their local assemblies, chiefs and Members of Parliaments for assistance to advert the effect of losing their farm lands to investors. Abease reported the highest percentage of households (13\%) not going to their local assemblies for help for the past twelve months. However, the computed indices showed that farming households in all the study communities and the Pru East district (0.07) as a whole experience low effect of large-scale land acquisition on households who report not going to their local assemblies for assistance. Prang has farming households staying in the community relatively longer than farming households in other communities. Farming households who have stayed in their current communities for a long period of time are deemed to have more associations with other households who can assist them to easily adjust to the loss of their farm lands relative to farming households with short stay in their communities. The computed district index (0.39) showed that large scale land acquisition has a low effect on the duration of farming households stay in the community.

\subsection{Effect of Large-Scale Land Acquisition on Financial Capital Assets}

The financial indicator consists of nine sub-indicators. Size of farm land owned by a household is a proxy for the wealth level of the household. Farming households in Prang held the highest average farm size owned by households. The computed district index for farm size ownership revealed that large scale land acquisition has a high effect on households' farm land ownership. Adjentura is the community with farming households cultivating the highest average acres of farm land in the Pru East district. The computed district index of 0.60 suggest that large scale land acquisition posts moderate effect on the size of farm land cultivated by farming households in the 
district. The computed district index of 0.87 implies that large scale land acquisition has a high effect on farming households depending solely on agriculture as a source of livelihood. Kobre community recorded the highest percentage (100\%) of households depending solely on agriculture for their livelihood. The next sub-indicator of the financial indicator is the percentage of households reporting loss of house or property due to large scale land acquisition and Abease community had the highest percentage of households attributing loss of property to large scale land acquisition. The index of 0.63 reveals moderate effect of large-scale land acquisition on farming households loss of houses or property. The value of the assets (farm lands, houses, economic trees, etc.) owned by a household determines its' level of livelihood.

The research finding also revealed that all farming households in Kobre and Abease communities do not have access to financial services. The computed district index (0.93) showed that large scale land acquisition has a high effect on households without access to financial services. Adjentura community has the highest percentage of households without any household member working in a relative developed community/town. The index of 0.86 computed for the Pru East district indicates that large scale land acquisition has a high effect on the livelihood of farming households without any member working in a different relative developed community/town. Households with members working in other communities/towns may receive remittance or transfer payments to support themselves especially when their farm lands are taken over by investors. Large scale land acquisition posts high effect on the livelihoods of farming households reporting financial crisis as indicated by the computed district index $(0.90)$. Kobre community recorded the highest percentage $(100 \%)$ of households reporting financial crisis. However, the computed district index of 0.39 portrays low effect of large-scale land acquisition on the average incomes of farming households. All households in Adjentura attributed reduction in their incomes to large scale land acquisition by investors. The computed index for the district $(0.79)$ revealed that large scale land acquisition has a high effect on the livelihood of farming households attributing reduced incomes to large scale land acquisition. Households that have more networks and relations including access to financial services and household members working in different communities will least fell the effect of large-scale land acquisition on their livelihoods.

\subsection{Effect of Large-Scale Land Acquisition on Physical Capital Assets}

The fifth indicator of the Livelihood Effect Index is the physical capital and includes households' basic needs and access to basic physical amenities. Three sub-indicators comprise the physical capital indicator. The first subindicator is the percentage of households attributing changes in their road network to large scale land investment and almost all households in all the study communities did not attribute the changes in the road conditions in their communities to large scale land investments. The computed district index of 0.13 indicates that large scale land investment has low effect on the road network of farming communities in the Pru East district. Adjentura recorded the highest percentage of farming households without access to farming inputs. The computed district index of 0.56 shows that large scale land acquisition has moderate effect on farmers' access to farming inputs. Finally, agricultural livelihood diversification is crucial in ensuring good livelihood of farming households. Households in Prang community are the most affected community on the effect of large-scale land acquisition on agricultural diversification. The computed district index of 0.35 shows that large scale land investment has low effect on the agricultural livelihood diversification of farming households in the Pru East district.

The indices for the indicators of the Livelihood Effect Index were computed by averaging the sub-indicators indices constituting each of the indicators. This is presented in Table 3.

Table 3: Computed Indicator Indices of LEI

\begin{tabular}{lllllll}
\hline Indicator & Kobre & Adjentura & Kadue & Abease & Prang & Pru East Dist. \\
\hline Human & 0.65 & 0.56 & 0.66 & 0.50 & 0.59 & 0.61 \\
Natural & 0.65 & 0.56 & 0.60 & 0.54 & 0.59 & 0.62 \\
Social & 0.28 & 0.29 & 0.32 & 0.33 & 0.31 & 0.30 \\
Financial & 0.76 & 0.76 & 0.73 & 0.71 & 0.68 & 0.73 \\
Physical & 0.29 & 0.34 & 0.33 & 0.35 & 0.33 & 0.33 \\
LEI & $\mathbf{0 . 5 3}$ & $\mathbf{0 . 5 0}$ & $\mathbf{0 . 5 3}$ & $\mathbf{0 . 4 9}$ & $\mathbf{0 . 5 0}$ & $\mathbf{0 . 5 1}$ \\
\hline
\end{tabular}

The computed indicator indices showed that farming households in the Kadue community (0.66) are more affected with the effect of large-scale land acquisition than households in the other communities in terms of human capital. This is shown in Figure 2. The computed district index of 0.61 suggests that large scale land acquisition has a high effect on the human capital of farming households in the Pru East district.

On natural capital, Kobre community with an index of 0.65 showed that farming households in the community experienced the highest effect of large-scale land acquisition on natural capital than farming households in the other study communities. The computed district indicator index for the natural capital indicates that large scale land acquisition has a moderate effect on the natural capital of farming households in the Pru East district. This finding is consistent with Gobena (2010) who reported increased natural resources degradation resulting from deforestation and land conflicts attributable to the influx of foreign land deals in Bako-Tibe Woreda in Ethiopia. 
The effect of large-scale land acquisition on the social capital of farming households in the Pru East district is low (0.30) with households in the Abease community (0.33) being the most affected. The findings of this study support Gobena (2010) who reported a negative implication of farmers' of Kebele dispossession of farm lands to Indian investors in Ethiopia on their social livelihoods especially when the investors disregarded the social values of the native farmers by clearing trees at locations designated for the performance of their traditional practices.

The computed financial indicator of 0.73 implies that large scale land acquisition has a high effect on the financial capital of farming households in the district with farming households in Kobre and Adjentura communities (0.76) being the most affected. A physical capital index of 0.33 for the Pru East district reveals that large scale land acquisition post low effect on the physical capital of farming households in the Pru East district and Abease with an index of 0.35 is the most affected community. This is presented in Figure 2.

Figure 2: Radar diagram showing the study communities' LEI indicators

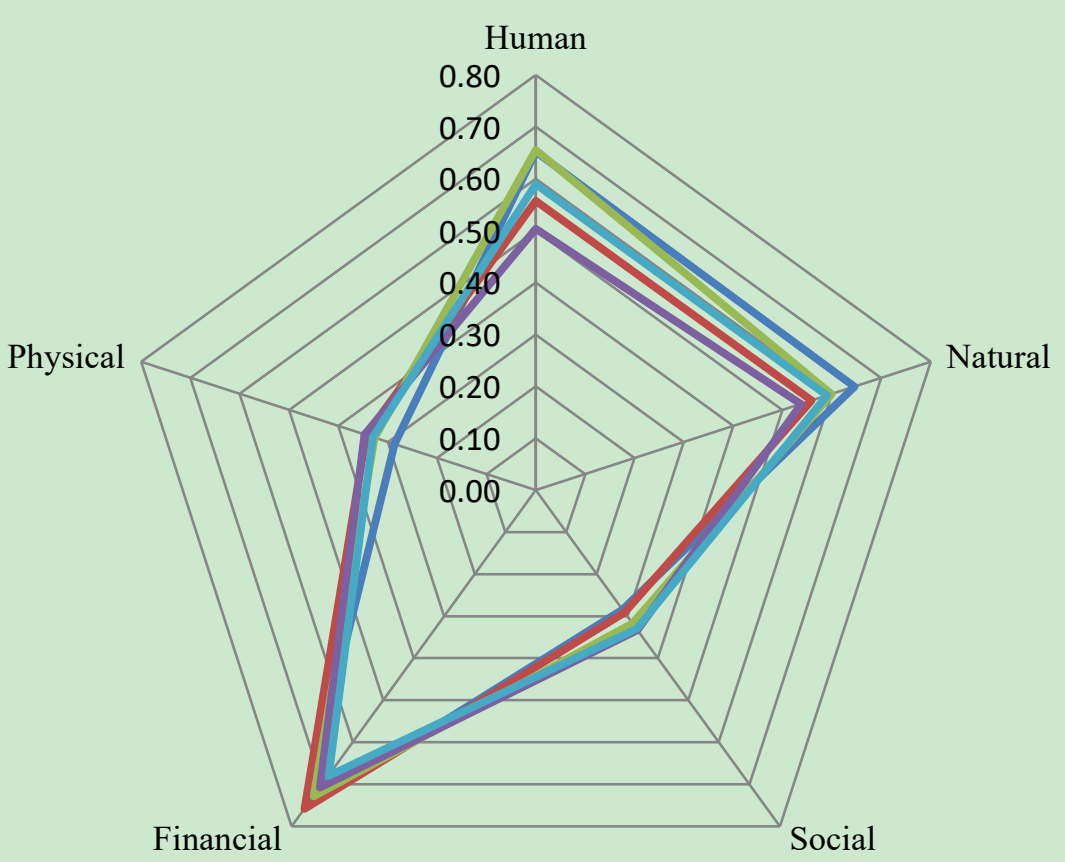

Kobre

Adjentura

Kadue

Abease

Prang

Averaging the five indicators of the Livelihood Effect Index showed that the Kobre and Kadue communities with an LEI of 0.53 suggests that livelihoods of farming households in these two communities are the most effected with large scale land acquisition. This is presented in Figure 3. The computed LEI for the Pru East district is 0.51 which shows that the effect of large-scale land acquisition on the livelihood of farming households is moderate. Similar findings were reported by Williams et al. (2012) who found that large scale lands acquired for Jatropha plantations in the Yendi Municipal, Pru and Nkoranza districts had significant negative effects on the livelihood of farmers because displaced young farmers could neither get employment with the company nor access fertile farm land for cultivation. 


\section{Figure 3: Line graph showing Livelihood Effect Indices of Study Communities}

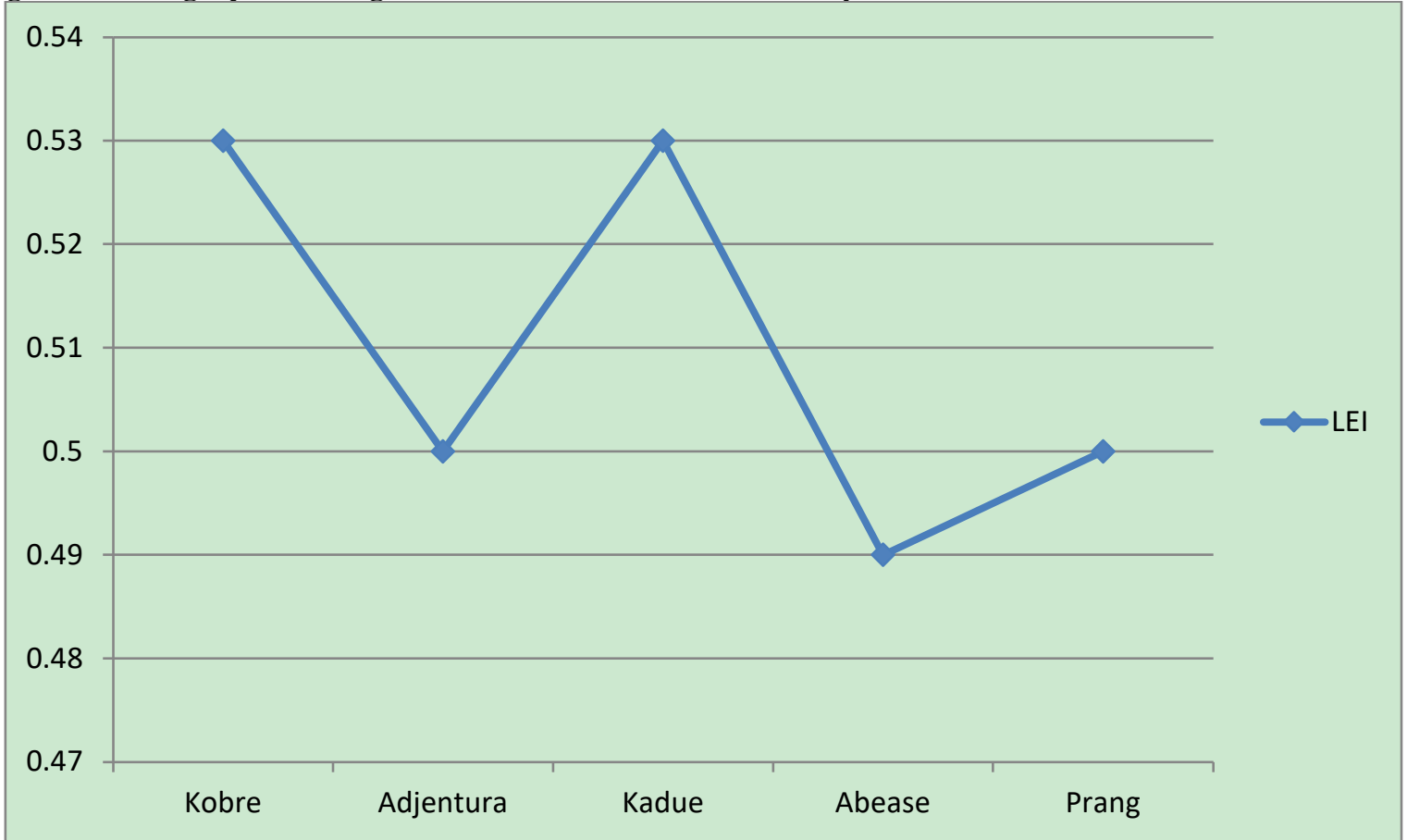

To test for the statistical significance of the effect of large-scale land acquisition on the livelihood of farming households, the computed household's LEIs was correlated with households' responses on whether it has lost any land to large scale land investors. The correlation results presented in Table 4 shows that the Pearson correlation coefficient $(0.305)$ is significant at 5 percent. This means that large scale land acquisition has a significant effect on the livelihood of farming households. The null hypothesis is therefore rejected.

Table 4: Correlation results on the effects land investment on households' livelihood

\begin{tabular}{llll}
\hline Pearson Correlation coefficient & № of respondents & Significance. & Decision \\
\hline 0.305 & 332 & 0.023 & ${\text { Reject } \mathrm{H}_{\mathrm{o}}}$ \\
\hline
\end{tabular}

\subsection{Conclusion}

Large scale land acquisition has a significant positive moderate effect on the employment, healthcare and food security but, has a significant negative high effect on income levels of smallholder farming households. However, large scale land acquisition has no significant effect on the nutritional status of farming households in the Pru East district of the Bono East region. Empirical findings showed that the size of households' farm land relinquished to large scale land investors significantly exacerbates the effects of large-scale land acquisition on the livelihood of smallholder farming households; lands which were acquired by companies whose operations are currently defunct should be returned to the initial occupants of these lands. This will be a panacea for farming households to expand production and also reduced the time spend in travelling to their farms. The study also recommends that MMDAs must formulate by-laws to ensure that large scale land investors employ people from the host communities of the projects. This follows the finding that large scale land acquisition has a significant positive effect on employment and few community members reported to be employed by large scale land companies. The reason is that though companies promised to employ workers from within their operational communities, they tend to flout this promise and are not held responsible by any institution or law because there is no such by-law which enjoins them to abide by the promise.

\section{References}

Abbink, J. (2011). Ethnic-based federalism and ethnicity in Ethiopia: Reassessing the experiment after 20 years. Journal of Eastern African Studies, 5(4), 596-618.

ActionAid (2010). Policy Briefing Paper on the Impact of Biofuel Production in Ghana. Published by Food Span coordination Secretariat, Accra Ghana. Pp. 1-8.

Alatinga, K. A., \& Fielmua, N. (2011). The impact of mutual health insurance scheme on access and quality of health care in Northern Ghana: The case of Kassena-Nankana east scheme. Journal of Sustainable Development, 4(5), 125-136.

Berdegué, J. A. (2013). The rapid rise of supermarkets in Latin America: Challenges and opportunities for 
development. Development Policy Review, 20(4), 371-388.

Bosch, C. and Zeller, M. (2013). The impacts of wage employment of jatropha plantation on income and food security of rural households in Madagascar: A panel data analysis. Quarterly Journal of International Agriculture 52(2), 119-140.

Bryman, A. (2008). The debate about quantitative and qualitative research: A question of method or epistemology? British Journal of Sociology, 35, 78-92.

Calcaterra, E. (2013). Defining smallholders'suggestions for an RSB smallholder definitions. Ecole Polytechnique Federale De Lausanne, 31(October)

Carney, D. (1998). livelihoods approaches compared: A brief comparison of the livelihood approaches of the UK department for international development (DFID). CARE, Oxfam and the United Nations Development Programme (UNDP).

Chambers, R., \& Conway, G. R. (1992). Sustainable rural livelihood: Practical concepts for the 21 st century. Cambridge: Institute of Development Studies Discussion Paper 296.

Cousins, 2010. Cousins, B. (2010). What is a smallholder? Class-analytic perspectives on small-scale farming and agrarian reform in South Africa. Working Paper 16, Cape Town: Institute for Poverty, Land and Agrarian Studies, University of the Western Cape.

Danso, W. (2015). Land grabbing for Jatropha Bio-fuel in Ghana; Assessing the impact on households' livelihood in Northern Ghana. Unpublished master's thesis, Norwegian University of Life Sciences.

Department for International Development [DFID], (1991). Sustainable livelihoods guidance sheets. DFID, London, U.K. URL: Retrieved from www.livelihoods.org/info/infoguidancesheets

DFID (2000). Sustainable livelihoods guidance sheets. www.livelihoods.org

Downing, T. E., Butterfield, R, Cohen, S., \& Huq, S., Moss, R. (2001) Climate change vulnerability: Linking impacts and adaptation. UNEP, Nairobi.

Ellis, F. (2000). Rural livelihoods and diversity in developing countries. Oxford: Oxford University Press.

FANRPAN. (2011). Measuring vulnerability-challenges and opportunities. Food Agriculture and Natural Resources Policy Analysis Network (FANRPAN), 2(11), 1-35.

Food and Agriculture Organisation [FAO], (2008). Compulsory acquisition of land and compensation. Rome: FAO.

Finco, M. V. A., \& Doppler, W. (2010). Bioenergy and sustainable development: the dilemma of food security and climate change in the Brazilian savannah. Energy for Sustainable development, 14(3), 194-199.

Giddens, A. (1979). Central problems in social theory: Action, structure and contradiction in social analysis. London: Macmillan.

Gobena, M. (2010). Effects of large-scale land acquisition in rural Ethiopia. The case of Bako Tibe Woreda. Unpublished Master's thesis, Swedish University of Agriculture, Sweden.

Hughes, A. K., Knox, A., \& Jones-Casey. K., (2011). Focus on Land Brief in Africa: Pressure on land from large scale biofuel production. World Resources Institute in partnership with Landesa Rural Development Institute. Funded by the Bill and Melinda Gates foundation.

Johnson, R. B., \& Onwuegbuzie, A. J. (2009). Mixed methods research: A research paradigm whose time has come. Educational Researcher, 33(7), 14-26.

Knight, R. S. (2010). Statutory recognition of customary land rights in Africa-An investigation into best practices for lawmaking and implementation. Rome: Food and Agriculture Organization of the United Nations

Kydd, J. (2002). Agriculture and rural livelihoods: Is globalisation opening or blocking paths out of rural poverty? Overseas development institute (ODI). Agricultural research and extension network (Algren).

Lakwo, A. (2006). Microfinance, rural livelihoods, and women's empowerment in Uganda. Uganda: African Studies Centre.

Levidow, L., \& Paul, H. (2010). Global agrofuel crops as contested sustainability, Part I: Sustaining what development? Capitalism Nature Socialism, 21(2), 64-86.

Liversage, H. (2010). Responding to land grabbing' and promoting responsible investment in agriculture. IFAD Occasional Paper, 978-92-9072-213-7

Makutsa, P. (2010). Land Grab in Kenya: Implications for Small-holder Farmers. Eastern Africa Farmers Federation, Kenya.

Mutopo, P., \& Chiweshe, M. (2015). Large scale land deals, global capital and the politics of livelihoods: Experiences of women small-holder farmers in Chisumbanje, Zimbabwe. Paper presented at the International Conference on Global Land Grabbing II. Organized by the land Deals Politics initiative.

Rahmato, D. (2011). Land to investors: Large-scale land transfers in Ethiopia. Addis Ababa: African Books Collective.

Rakodi, T. P. (2002). Market economy and urban change: Impacts in the developing world. London: McGrawHill.

Right and Resource Initiative (2012). Land grabbing in Africa. Retrieved from 
https://rightsandresources.org/en/blog/land-grabbing-africa-fueling-conflicts

Schoneveld, G. C. (2011). Land-based Investments for Rural Development? A Grounded Analysis of the Local Impacts of Biofuel Feedstock Plantations in Ghana. Ecology and Society, 16(4), 10-18.

Schoneveld, G., German, L., Andrade, R., Melissa, C., Caroko, W., \& Romeri-Hernandez, O. (2010). The role of national governance systems in biofuel development: A comparative analysis of lessons learned. Retrieved from http://www.cifor.org/publications/pdf

Schoneveld, G. C. (2011). The anatomy of large-scale farmland acquisitions in sub-Saharan Africa. Working paper 85. CIFOR, Bogor, Indonesia.

Schoneveld, G. C., German, L. A., \& Nutakor, E. (2011). Land-based investments for rural development? A grounded analysis of the local impacts of biofuel feedstock plantations in Ghana. Ecology and Society, 16(4), $10-25$.

Schoneveld, G. C., German, L. A., \& Nutakor, E. (2010b). Towards sustainable biofuels development: Assessing the local impacts of large-scale foreign land acquisitions in Ghana. Washington, DC: World Bank.

Scoones, I. (1998). Sustainable rural livelihoods: A framework for analysis. Retrieved from https://www.ids.ac.uk/publications/sustainable-rural-livelihoods-a-framework-for-analysis

Sindayigaya W. (2011). Foreign investments in agriculture: Land grabbing. Retrieved from http://www.entwicklungshilfe3.de/fileadmin/entwicklungshilfe

Tamrat, I. (2010). Governance of large-scale agricultural investments in Africa: The case of Ethiopia. Paper presented at the Annual Bank Conference on Land Policy and Administration.

Thurmond E., (2007). Feedstock trends: Jatropha. Retrieved from http://www.emergingmarkets.com/media/index.html

Tsikata, D., \& Yaro, J., (2011). Land market liberalization and trans-national commercial land deals in Ghana since the 1990s. Panel 8, Political Economy: Estate and Out growers. Sussex, UK: Land Deal Politics Initiative and Journal of Peasant Studies. Future Agriculture Consortium at the Institute of Development Studies (IDS).

Vermeulen, S. \& Cotula, L. (2010). Over the heads of local people: consultation, consent and recompense in large-scale land deals for biofuels projects in Africa. International Institute for Environment and Development (IIED), the Food and Agriculture Organisation of the UN (FAO) and International Fund for Agricultural Development (IFAD)

Williams, T. O., Gyampoh, B.; Kizito, F., \& Namara, R., (2012). Water implications of large-scale land acquisitions in Ghana. Water Alternatives, 5(2), 243-265.

Woodhouse, P. (2012). Foreign agricultural land acquisition and the visibility of water resource impacts in SubSaharan Africa. Water Alternatives, 5(2), 208-222. 